\title{
Local Political Democratization Policy: Voter Participation in the Direct Regional Head Elections
}

\author{
Winengan \\ Universitas Islam Negeri Mataram \\ (email: winengan@uinmataram.ac.id)
}

\begin{abstract}
The regional head election, a local political event and a symbol of democratic government, is a contest for a legitimized power of regional leaders, who are given authority and responsibility to administer and lead the regional apparatus and development. Since the Indonesian reformation era, the policy regarding the regional head election has shifted from being elected by the local legislative assembly (representative system) to being elected by the people directly (direct election). Anchored in the quantitative descriptive research design, in which the data was garnered from documentation, this study aims to examine the extent to which the people partook in the first round of the direct and simultaneous regional head election in 2015. The collected data was analyzed by means of the participatory and democracy approach within the local political landscape. The empirical findings showed that the public participation in the local election remained low given the statistical evidence ( $64.02 \%$ of the total voters). The study demonstrates that despite the provision of the political stage within the local scope, it does not fully encourage the people to exercise their political rights.
\end{abstract}

\section{Keywords:}

regional head election; democracy; election; participation

\section{Introduction}

The Indonesian political choice in using the democratic system for its governmental operation has contributed to the state development both in terms of structure and culture. The regional head election is a local political event and a symbol of Indonesia as a democratic state, as stipulated in the basic law of the Indonesian Republic 1945. Practically speaking, the policy regarding the regional head election mechanism should be based on the political lives, social dynamics, development and progress of the state democracy, and on explicit regulations. The main actors in the elections consist of community, political parties, and candidate contestants (Fenyapwain, 2013, p. 1).
Since Indonesia's independence, the election of the regional head is regulated through Law No. 5/1974 regarding the local government. The law posited two functions: as an autonomous local government who led and was fully responsible for the local governance and as a regional government who represented the central government regarding general matters at the regional levels. However, based on the policy of Law No. 5/1974, looks that the attitude of the very authoritary center government, because not provide the room for local community to participate in distributing the political rights at the local level.

However, since the fall of the New Order, which was possible because of reform waves in 1998, there has been a significant shift in the 
regional government system, which generates a new mechanism for carrying out the regional head election. In contrary to the New Orde era, the regional head was decided by the president or minister of home affairs; they no longer have had such an authority since the Reformation era. The amendment of the basic law 1945 brings about significant shifts pertinent to the regional head election system, for instance, the article 18 para (4) basic law 1945, which stipulates that the governor, regent, and mayor, who respectively head the province, regency, and city, are elected democratically.

The term elected democratically has been actualized in two ways. Firstly, the regional head election is done directly, freely, secretly, honestly, and fairly by each member of the regional legislative assembly (representative system). Secondly, the regional head election is done directly by each regional people, without the representative system as elected by the regional legislative assembly with the stipulation that the candidate with $50 \%+1$ voices would be determined as the winner to lead the region for five years.

Until the regional head elections of 2015 , the direct participation of every regional people is still an ideal choice in the mechanism of enforcing the political democratic rights of regional peoples. The implementation of the direct and simultaneous election on December 9,2015 , both at the provincial, district and municipal levels, was relatively democratic, safe and peaceful, which reaped a positive appreciation from a number of people, including observers, as a democratic experiment that was so admirable and commendable. However, the public participation remained low. The data taken from the general election commission showed the public participation in the direct and simultaneous regional head election on the December 9, 2015 was $64.02 \%$ on average of the total expected voters (Tashandra, 2015).

Even in some regions, the level of participation was below $50 \%$. Other reports also evidenced such a low participation in several cities and regencies, which included Medan city $(26.88 \%)$, Serang regency (50.84\%), Surabaya $(52.18 \%)$, Jember regency $(52.19 \%)$, Tuban regency $(52.25 \%)$, and Mataram city $(56.94 \%)$. On the other hand, some other regions with relatively high participation were Central Mamuju regency $(92.17 \%)$, South Sorong Regency (89.92\%), East Bolaang Mangondow $(88.83 \%)$, Tomohon city $(88.47 \%)$, and North Konawe $(88.24 \%)$. Despite the facts above, the general election commission targeted the public participation in the democratic event to be around $75.5 \%$ (Tashandra, 2015).

This low participation had come to the fore and remained mostly reported by the mass media in Indonesia. From the 358 media outlets that reported the regional head election in the country, the public participation appeared to be appealing. As a result, the issue of voting in the direct regional head elections system got a lot of attention, because it was not in line with expectations of good local governance and decentralization policies (Erb \& Sulistiyanto, 2009). This study looked into the public participation in exercising their political rights regarding the five-year democratic event in the regional level framed under the direct and simultaneous regional head election.

\section{Methods}

This research is designed as a descriptive qualitative research that intends to study the case of low voter participation in the first round of the direct and simultaneous regional head election 2015. With reference to the locus of the data collection, this research belonged to the literature study, in which the data was collected by means of a documentation technique as it made use of the existing literature resources, such as books, journals, Internet, and relevant previous research findings; therefore, the data in this study was categorized into secondary data. Subsequently, the data was analyzed through the use of theories relevant to the 
participatory study of people in the regional political context.

\section{Results \\ The Empirical Problems of the Direct Regional Head Election}

The regional head election is a contest for a legitimized power of regional leaders, who are given authority and responsibility to administer and lead the regional apparatus and development. In other words, the direct regional head election is a political expansion of the people and as a form of the people's sovereignty in determining the figure of the regional leaders in accordance with the hopes and aspirations of the people, and it has strong political legitimacy (Simamora, 2011, p. 229). Drawing on the context of the regional head election in democratic countries, the concept that underpins the public participation has basic ideologies that people have the right to decide their own leaders, who will later determine the public policy for the sake of social purposes. These democratic nations posit that the people hold the supreme power over the states' sovereignty (Mudjiyanto, 2012, p. 1), hence their political participation should be taken into account.

Historically, the first direct election was held in 2005 in Kutai Kertanegara Regency. It turns out from year to year and raises issuesrelated to regional readiness in conducting regional head elections, implementation issues schedule, stages and program of regional head election, fulfillment of candidate of regional head and vice regional head and other issues related to execution at field (Nuryanti, 2015, p. 126).

The direct and simultaneous regional head election was held on December 9, 2015, in 8 provinces, 222 regencies, and 34 cities across Indonesia. However, there remains a rise of fraudulent claim regarding its implementation (Sahdan \& Haboddin, 2009, p. 57). Similarly, the general election commission as the legal institution administering the national and regional head election argues the same thing that the results of the first period of the direct and simultaneous regional head election argued for. In fact, it left several problems due to the rejection of the results by lost candidates drawing on 147 lawsuits. On the other hand, the primary object of the plaintiff basically centered on the accusation of fraud throughout the election. Such accusations included money politic, the involvement of a state civil apparatus, partiality of the election organizer, and the data manipulation pertinent to the election (KPU, 2015, p. 7).

The accused frauds committed by the election organizer were also reinforced by the provision of the data of violation of the code of ethics of the election committee in the Board of General Election Organizer. Since it was established on June 12, 2012 to March 2013, it has received 90 lawsuits related to violations of the code of ethics with the details of its decision as follows; sanction of dismissal: 5 chiefs of the general election commission and 15 members, 1 chief of election guard committee and 2 members, 5 members of Independent Commission of General Election; firm sanction or warning: 4 members of the general election commission, and 6 members, and 1 member of election guard committee; and written reminding: 1 chief of the general election commission (KPU, 2015, p. 52).

In addition, based on the data collected from the field, the implementation of direct and simultaneous elections in 2015 caused several problems (Budiman, 2015, p. 2), such as the following:

Firstly, the selection of the candidates did not go through a democratic system as they were fully determined by party officials at the central level (central board). The general election commission would only approve the candidates if they were proposed by the chief of the party board. If the candidates did not have any recommendation, the general election commission would reject their candidature, which was against the theory of representation. 
On the other hand, the regional heads, who were not able to represent their regions, would not be able to provide the best services to the community. Moreover, within several parties was a conflict of stewardship among the members, which confused the public of their political choices.

Secondly, there remained a dynastic system of politics in the direct regional head election, although the constitution No. 1/2014 regarding the governor, regent and mayor election had limited the spaces and opportunities for the growth of the political dynasty. Furthermore, the general election commission had stipulated the regulation No. 9/2015, which posits that progressive changes in diminishing the chains of dynastic politic from any angle. However, it changed after the constitutional court issued the stipulation of the election conflict No. 33/PUUXIII/2015 regarding the election of governors, regents and mayors against the law article No. 28J para (2) basic law 1945. The constitutional court initially indicated the government had violated human rights because it denied someone to candidate him or herself to be the regional head or vice of the regional head due to having a familial relationship with the current government. Therefore, there remained the dynastic power having controls in various regions given the latest regulation. The growth of the political dynasty did not mean that the public was satisfied with their performance, yet the money politic hampered the transactional politic, which brought about the dilemma about the regional governance.

Thirdly, there appeared the replacement of the two-round systems with the first past the post (FPTP) in determining the winning candidates. The former allowed the candidates to gain public support by means of a simple majority (a minimum of $30 \%$ ), so it relatively affirmed their legitimacy in the region. On the other hand, the latter limited the public support (legitimacy) because the regional democracy through the regional head election would not run the second round of elections should there have been a disparity between the winning candidates, and the plaintiffs were small (2\%).

Fourth, the constitution No. 8 Year 2015 rejected the political parties that proposed candidates who gained foreign donors for their campaign. The central government, regional government, national state-owned enterprise and others with fictive identity, yet this law did not forbid the candidates from receiving any donors. With this regard, the regulation also obliged the political parties to propose candidates to open special bank accounts for the campaign purposes, yet it did not apply to the individual candidates.

Furthermore, according to the Ministry of Home Affairs of Indonesia, Tjahjo Kumolo (Lustrilanang, 2017, p. 16), there were some underlying problems arising during the direct and simultaneous regional head elections, which encouraged the anticipation of the following issues throughout the election periods: the availability of unregistered voters; Potential voters with no e-ID card; the lack of optimal role and function of the general election institution; the rise of questions regarding the issue of independency, integrity, and credibility of administering the election; the public participation after the election to become the balance for the state bureaucracy as a result of the election or elected officials; the lack of willingness of public in the general election; the provision of the political parties that often presented in the face of the general election; the existence of provinces with their local characteristics; ineffective law enforcement for elections with various problems, both technical and non-technical factors; the emergence of crucial issues, such as racial issues, money politics, campaign funds, abuse of power, bureaucratic political neutrality and mobilization of state civil apparatus that harmed the integrity of elections.

The emergence of various problems in the implementation of local elections directly above has been predicted before by the government, 
thus inviting the discourse to restore the direct electoral system into the hands of the Regional People's Representative Assembly (DPRD). This even appeared in the Plenary Session of the House of Representatives (DPR RI) on September 24, 2014, on the grounds that direct elections have high political costs, are vulnerable to the emergence of conflict, and do not guarantee the emergence of a good regional head (Nuryanti, 2015, p. 126). However, because the development of a democratic political system requires direct community involvement, the direct Regional Head Election is finally maintained, as a manifestation of the repatriation of the "basic rights" of the community in electing its regional leaders (Sundari \& Ishak, 2017, p. 1).

\section{The Degree of Voter Participation in the Direct Regional Head Election}

The transformation of the regional governance system into a more democratic one as stipulated by the regional autonomy has brought new hope to the realm of regional politics. In the democratic development perspective within the local scope, the approved regional autonomy becomes a promising milestone as it affords wider opportunities for the public to participate in determining their regional governments (Tejo in Karim, 2008, p. i). The existence of the direct election policy is one of the symbols of upholding democracy at the local level. It has created a stage for the community to exercise their political rights, as well as to manifestat political modernization in the democratic state (Sundari \& Ishak, 2015, p. 3).

The direct regional head election is a result of reforming the local government system to a more democratic direction, which aims to give local people the opportunity to determine their regional leaders directly. A direct regional head election, when viewed from the theory, has a very strong legitimacy because the elected regional head is directly elected by its constituents. Constituents in this case are given the opportunity to participate in determining the local government. Thus, elected regional heads, besides possessing strong legitimacy, are expected to bring regional heads with an orientation to improve the welfare of their people (Nuryanti, 2015, p. 127).

For this reason, the election of regional government through a representative system by the local legislative assembly has been deemed irrelevant to the demands of emerging democratic values as it makes the candidates remain unrecognized by the people in the region. The phenomenon of low public participation in the 2015 direct and simultaneous regional head election was caused by several factors (Fachrudin, 2015), as follows:

Firstly, the regulation factor; the Law No. $8 / 2015$ regarding the regional head election or The Regulation of the General Election Commission No. 7/2015 about the electoral campaign of the governor and vice governor, regent, and vice regent, mayor and vice mayor, which limited the rooms for the candidates to socialize as stipulated by the regional head election commission at the municipal, regency, or provincial levels, particularly regarding the installment of banners in public spaces. Such a regulation lessened the joy of the regional head election, which harmed the public's interest in exercising their political rights.

Secondly, a number of political parties entitled to carry candidates in the local elections were experiencing internal conflicts, and there had been no verdict with permanent legal force. The internal conflicts that occurred within the political party board not only made it difficult for them to process and propose candidates who had a high degree of electability and popularity, but also resulted in voters, especially the constituents, becoming less enthusiastic to support wholeheartedly the candidate couples proposed by the political parties.

Third, the candidates promoted by political parties or those from independent candidates were deemed to lack the electability, 
thereby reducing public trust on the elections, political institutions and candidates themselves as the instruments capable of making changes and community improvement. As a result, voters became apathetic and remained reluctant to go to the voting center.

Fourth, the people were reluctant to go to the voting center due to the absence of their name as permanent voters, or they did not gain an invitation letter for the election (known as C6), which was often caused by the negligence of the regional head election commission. However, without the letter of invitation, the people could vote as long as they were registered in the election center.

Another factor that caused the low participation of the public in the direct and simultaneous regional head election, drawing on the result of the Indonesian Survey Institute, was the change of mode of campaign, which was mostly arranged by the general election commission through media, such as banners, posters, etc. (Ambardi, 2015). Furthermore, according to the Polmark Survey Institute, the limited amount of time given to socialize to the public also contributed to the lack of participation in the regional head election (Akbar, 2015). On the other hand, the general election commission argued that the lack of participation of the public in the 2015 regional head election was caused by the lack of the role of the candidates to ensure the people's awareness to exercise their political rights, which happened because the promoting team did not work.

\section{Discussion}

\section{Dynamics of the Direct Regional Head Election Policy}

The election of regional heads (Pilkada) is a contest for the legitimacy of power held by a person in order to lead the way in the process of governance and regional development. In other words, Pilkada is a mechanism of selection and delegation of authority to someone who has the legitimacy to fill the positions of local government leadership (Surbakti, 1992, p. 181).

In the context of the election of regional heads, in countries that embrace democratic ideals, the idea of people's participation has an ideological basis that the people have the right to decide who will be the future leader and to determine public policy for their welfare. Countries that adopt a democratic system are states that view the existence of its citizens as the owner of sovereignty in the country (Mudjiyanto, 2012, p. 1), so that its political participation cannot be ignored.

The election of regional heads has been an important issue since independence, and it has become one of the main characters in the provincial and district governance system of Indonesia (Mboi, in Earb \& Sulistiyanto, 2009). However, the Provision of the Constitution No. 32/2004 adding perfection to Law No. 22 /1999 about the regional government has impacted on the reform of the mechanism for the regional head election per se, which aimed to generate a better, more effective and efficient election procedure in accordance with the dynamics of political life and the development of democracy in Indonesia, where all regional heads were elected directly by the people of each region (Nugraha 2016, p. 73).

The direct regional head election is a manifestation of political autonomy due to the decentralization policy of local governance. It is an important means of enforcing democratic values at the local level to enable people to partake in choosing their leaders who control and lead the regional development policies in a better direction (Sari, 2016, p. 87). In addition, it is a means of manifesting the sovereignty of the people (Simamora, 2011, p. 229), in order to get local government elected in a democratic way in accordance with the 1945 Basic Constitution of the State of the Republic of Indonesia.

Unfortunately, the local democratic process of local politics through direct local elections in Indonesia demonstrates a negative 
practice, largely due to the politics of money, and is dominated by local elites (Aspinall, 2010), so that although Indonesia is considered successful in building its democracy, in terms of quality, it is still relatively low, which is a result of the political business conspiracy or hijacked interest groups; it ignored the real purpose of fighting for the decentralization of local politics (Hadiz, 2004). In addition, the decentralization policy that gave birth to local direct election systems has weakened accountability in the regions (Sjahrir et. al, 2014). The direct mechanism of local elections with the aim of strengthening the democratic accountability of local governments is ineffective. This, among others, is seen from the indication of corruption that has not decreased significantly, but it is decentralized and disorganized (Hill, 2012).

The direct election policy of regional heads as a form of community independence in determining their leaders at the local level has in fact resulted in a spate of corruption at the local level (Rumesten, 2014). In fact, the Ministry of Internal Affairs noted that during the years 2005 to 2015, more than 350 provincial and district heads dealt with law enforcement because of an abuse of authority. This means that the direct election of regional heads as a form of circulation of leadership at the local level has only led to a type of leadership that is coincidentally chosen by the people and has considerable capital, not because of the competence and creativity of its leadership (Labolo, 2015, p. vi).

They remained skeptical of the regional head candidates for the coming five years due to the fact that many regional governments in Indonesia misused their rights and were allegedly caught in corruption (Sjahrir et. al, 2014). In addition to that, the people also assumed there would be no betterment at the regional levels through the regional head election. Hence, either participating or not in the regional head election did not have any effect on the betterment of the region. This was legitimized by the fact that during the regional head election, there were a number of money politics, so it was reasonable that a myriad of local governments were allegedly corrupt as they needed to return their expenses during the election (Sari, 2016, p. 87).

However, there appears to be a big consequence because it generates big political campaigns, which requires much funding from both the national and local budgets (Sari, 2016, p. 87). The average expense for the mayor and regent elections is twenty-five billion, and five hundred billion for the governor election. Within five years, there has been thirty billion in state funding used for the regional head election. Meanwhile, on the other hand, the participation of voters in the local direct election system is also likely to decline. However, with the change of direct local elections, the system is simultaneously considered to cut half of the budget (Budiman, 2015, p. 13).

The existence of various problems that occur in the direct election of regional heads should not be used as a basis to say that local democratization policies or local political autonomy is not suitable for Indonesia. Local political policy must be maintained, as it can be a means of political education, deliberation, and realizing accountable local government for regional progress. In addition, according to Putnam et al. (1994), the direct election of regional heads can be a means of democratic participation of the community to demonstrate commitment, trust and cooperation in forming a civic community to build regional development performance. This idea also refers to the views of John Stuart Mill and proponents of participatory democracy at the local level, that opening taps for community involvement will support the creation of good governance and support for the achievement of social welfare (Suyatno, 2016).

Admittedly, the policy of local political decentralization in Indonesia has not shown significant results in better local governance, but 
rather on budget wastage (Hill, 2012). However, for the sake of political empowerment of the people, this policy of local political democracy must remain guarded, because this political democracy is a system of government in which those who have authority to make decisions (that have the force of law) acquire and retain this authority either directly or indirectly as the result of winning the free election in which the great majority of adult citizens are allowed to participate (Burns, in Saifudin, 2009: 13)

The practice of local political democracy, which places the participation of society as its essence, as in the direct elections of regional heads in Indonesia, according to Habermas (Hardiman, 1993, p. 76), is an ideal form of common life that must be fought for. Although the ideal situation cannot be fully achieved, the most important thing is that the principle of handling to achieve the "ideal state" is continuously enhanced and rejects all kinds of obstacles, either the barrier of freedom of voice of opinion or the avoidance of isolation of social groups.

Starting from some views about ideal democracy in the system of governance, both central and local, direct elections are still facing problems (Nuryanti, 2015, p. 126) and voter participation is still low (Sundari \& Ishak, 2017, p. 5). This should not be an excuse to return the election mechanism to the representative system, sick, there are other activities, again outside the city), jobs (working and not getting permission), administration (moving, not having identity card/KTP, and not getting invitations), socialization (not knowing candidates, not knowing, and confused), and political (do not believe in candidates and saturated) (Arianto, 2011, p. 56-59).

As for addressing various problems in the direct election of regional heads, there is no other way, unless all regional elements (government, private, and civil society) participate in totality, with their knowledge, attitude and actions that must be directed to maintain and run the stage the local democracy is in accordance with the established rules of the game. Not participating falsely, that participation is born because there is a certainty or payment by certain parties.

\section{Measure the Degree Lower of Voter Participation in Direct Regional Head Election}

The reform of the system of local government administration towards a more democratic direction that carried the policy of regional autonomy has issued new hope in local political life. In the perspective of democratic development at the local level, the enactment of this regional autonomy policy is certainly a good sign, since the involvement of the community in the local political arena is increasingly wide open (Karim, 2008, p. i). The opening of the public political participation taps is a form of the care of democratic values at the local level as well as the objectives of the decentralization policy (Muluk, 2009).

Political participation is the core of democracy, so it is one of the logical implications of a democratic system adopted by a state, because political participation will not occur if a country's political life is not built on democracy (Huntington and Nelson, 1977, p. 3). Even political participation is at the heart of democracy. Democracy cannot be imagined without the ability of citizens to participate freely in the state process. In the view of Herbet McClosky (in Budiardjo, 1981, p. 1), political participation is a voluntary activity of citizens to take part in the electoral process of the ruler and the process of forming general policies, both directly and indirectly. However, voter voting in the general election is considered to be the least active form of active political participation, since it requires minimum involvement, which will cease if the vote has been implemented (Rush \& Althoff, 2007, p. 122).

In Indonesia, to facilitate the political participation of local communities through this voting action, the government issued a 
policy of local political democratization in the form of direct regional head elections by each community based on Law No. 32 Year 2004 on local government (Hidayat in Erb \& Sulistiyanto, 2009). Unfortunately, the local political democracy facilities are not well utilized by local communities. This is evident from the low level of voter participation in channeling their voting rights in the direct elections of regional heads held in various regions from 2005 to 2015 (Tashandra, 2015).

There are still many apathetic local people in the smallest active political participation (Rush \& Althoff, 2007, p. 122). The low participation of the public in the 2015 election at the regional levels indicated the failure of carrying out the five-year democratic tradition given the low and high participation of the public as one of the indicators of the success of the administration of such a regional head election (voter turn out) (Fachrudin, 2015). In addition, it also indicated the lack awareness of the public regarding the political life, which impacted on the lack of public's interest in promoting the democracy in their regions, as according to Huntington and Nelson (1977, p. 3) who argued that the high participation of the public indicates that they were aware of and having the democratic lives in their state.

Based on empirical data, the low voter participation in direct regional head elections in various regions in Indonesia, which can only reach an average of $64.02 \%$ (Tshandra, 2015), is at least caused by three factors:

First, the mistrust of voters against candidates for regional heads to apply the mandate and ability to carry out the task of regional leadership. This attitude is triggered by the many corruption cases that hit regional heads in Indonesia, and most of them are from politicians, not professionals. These voter typologies tend to think rationally and have higher levels of education. The mistrust of the voters in transforming and bettering their lives, in the context of direct election, the primary reason for the public not to fully participate in exercising their voting rights (Laurian, 2004).

Second, pragmatic, that is, voters feel they do not get any benefit from the election of the regional head. The election of regional heads is considered to benefit only political elites who expect certain positions in local government. The typology of this voter generally comes from the lower economic community with low education levels. They will choose if given material rewards, so often the target of money politics team of candidates for regional head. The low voter participation is not because it is unconscious and does not consider political participation important, but because they feel no real benefit will be obtained for themselves (Mao, 2010). The people participation was driven by the economic interest (Agus, 2016).

Third, the disinterest of voters against candidates who advanced as contestants of local elections. This may be because among the candidates, it is considered that no one represents his identity, whether tribal, religious, ethnic, professional, group, and others. This typology tends to be traditional and militant. In fact, according to Pratikno (Erb \& Sulistiyanto, 2009), the low level of active participation of the community in the direct election of regional heads in Indonesia is a manifestation of the traditional ways or attitudes of grassroots communities in protesting the political system, the sense of aversion, pessimism, areas dominated by the elite.

The low level of voter participation in the direct election of regional heads in various regions of Indonesia has nothing to do with the influence of ethnicity factors and low levels of education (Curvale, 2013), residential areas between cities and villages (Mao, 2010 ), and communication and information issues (Mikkelsen, 2011, p. 57). This reasoning is based on the empirical fact of the recapitulation of the number of voters in the direct election of regional heads by 2015, where the number of electors to the mayors, the urban voters, whose 
education tends to be higher, and the distric head, whose voters are from rural communities, education is lower, does not indicate any significant gaps. Whereas in the case of communication and information, there is no reason for the local community not to know the existence of the election of the regional head, because the various elements involved in the direct election of regional heads, looks very active in disseminating information, either through the media or directly.

The low participation in the regional head election was surely not equivalent to the development of democratic values in the regional system, because democracy was regarded as an ideal system of governance of certain states due to the involvement of the people as the ones who held the supreme sovereignty (Gaffar, 1992, p. 106). Additionally, the implementation of democracy as an ideal concept in the governance of certain states with the supreme sovereignty under the people (Mudjiyanto, 2012, p. 1), would afford the opportunities to realize the following: effective participation: people have the wider chance to improve their political participation; equality in voting: people have equal rights to speak out their opinions without any legal threats regarding the political matters; gaining enlightened understanding: people have the rights to gain pure understanding from alternative resources of information; exercising final control over the agenda: People have the opportunity to constitutionally control the government agenda regarding the policies; and inclusion of adults: adults have the rights to elect in the executive elections (Dahl, 1998, p. 38).

The emergence of the factors above reaffirmed what had been stated by Slamet (2001, p. 43), that the public participation as voters would not be realized unless the following supporting factors were fulfilled: the chance availability, which is the situation in which the people are aware of their participation opportunity, the provision of willingness, which is something that encourages the interest and attitude of the people to participate, such as the benefit of their participation, and the provision of wants, which is the awareness or belief on themselves that they have the ability to partake, either in the form of thoughts, power, time, facilities, and other materials.

The democratic concept that placed the public participation at its own right was an ideal life of collectiveness, which should be upheld. According to Habermas (as cited in Hardiman, 1993, p. 76), democracy was an ideal life of collectiveness. The people participating in the political sphere, such as in the direct election, was regarded to have the positive values because it made the democracy become more valuable, and influenced the government to be more responsive and affirmative to the establishment of the civilian responsibility.

The extent to which people partook in the election did not occur by itself, but rather by the availability of the information and technology, supporting institutions, structures and social stratification, local culture and politics. In addition, Paige (in Saifudin, 2009, p. 19) opines that there has been causal correlation between the political awareness and public participation as voters: if the political awareness and beliefs on the government are high, the public participation tends to be active; if the political awareness and beliefs on the government are low, the public participation tends to be pressured (apathetic); if the political awareness and beliefs on the government are low, people will be militant and radical; and If the political awareness of the people is low, yet the beliefs in the government are high, people participation tends to be passive.

To establish high quality democracy and to boost public participation in the regional head election required an attempt to make the people aware or to train them about participation, not just as a right but as an obligation of the whole society by involving multiple elements, such 
as educational institutions, communication media, and executives (Shehu et al., 2013). This negated the result of analysis that poverty and low education were not the barriers for the people to participate in exercising their political rights (Thananithichot, 2012); even ethnicity was not the determining factor for the political participation (Curvale et al., 2013). The public awareness was very much influenced by their motivation (Laurian, 2004).

Finally, low voter participation in the context of the local direct election in Indonesia should be seen as a process of democratic maturation at the local level. If expecting an increase in voter participation, the direct elections should appear more attractive to voters, so the public does not assume there is no correlation between the electoral process and the performance of the regional head that the community can enjoy directly (Muhammad, 2015). In addition, improving the quality of political parties and improving the economic and educational political conditions of the people is a factor that should be given attention, because it has an influence on increasing the political participation of the community (Arwiyah, 2012, p. 86-90).

\section{Conclusion}

Drawing on the perspective of decentralization policy, the direct election is a meaningful breakthrough towards the process of democratic consolidation at the regional level. It will afford a wider opportunity for the people to partake in the democratic process for determining their political leadership in the regional scope. This system also allows the people to better actualize their political rights without being reduced by political elites. The direct election also generates the emergence of aspiring, competenrgent, legitimized, and dedicated figure. This is certainly because the elected regional government will be more oriented to the people than to several political elites being his partners in the regional legislative assembly.
In addition to evidence of the provision of the public sovereignty, the direct election provides a strong legitimacy for the local government to head and manage the life of the people in the region through issued policies. For this reason, the local government will be closer to the people and more responsive to various problems and public interests. However, despite the availability of upholding the values of political democracy at the local level, the people do not fully make use such an opportunity to deliver their political sovereignty. The provision of reform in the management system of the political operation, low integrity and quality of the candidates on the public eyes, administrative issues in determining voters, and the lack of socialization and mobilization of the voters to exercise their political rights remain the empirical problems that discourage the people to partake in the direct regional head election.

\section{References}

Agus. (2016). Pemetaan sosiologis perilaku memilih di Nusa Tenggara Barat. Jurnal Transformative, 2(1), 1-15.

Akbar, M. (2015, Desember 11). Lembaga survei: partisipasi pemilih dalam pilkada serentak rendah. Republika.co.id. Retrieved from https://www.republika.co.id/berita/ nasional/pilkada/15/12/11/nz74qx336lembaga-survei-partisipasi-pemilih-dalampilkada-serentak-rendah

Arianto, B. (2011). Analisis penyebab masyarakat tidak memilih dalam pemilu. Jurnal Ilmu Politik dan Ilmu Pemerintahan, 1(1), 51-60.

Arwiyah, M. Y. (2012). Status sosial ekonomi dan kualitas partai politik dalam meningkatkan partisipasi politik. Jurnal Mimbar, 28(1), 85-92.

Aspinall, E. (2010). The irony of success. Journal of Democracy, 21(2), 20-34.

Budiardjo, M. (1981). Partisipasi dan partai politik. Jakarta: Gramedia Pustaka Utama. 
Budiman, H. (2015). Pilkada tidak langsung dan demokrasi palsu. Yogyakarta: Pustaka Yustisia.

Curvale, C. (2013). Citizen participation, social trust, and ethneic grouf in Ecuador. Asian Journal of Latin American Studies, 26(1), 75-96.

Dahl, R. (1998). Democracy. USA: Yale University Press.

Ambardi, D. (2015, December 11). Di balik partisipasi Pilkada 2015 'yang menurun'. BBC. Retrieved from http:// www.bbc.com/indonesia/berita_ indonesia/2015/12/151210_indonesia_ pilkada

Fachrudin, A. (2015, Desember 14). Menyoal partisipasi pemilih pilkada. Retrieved from http://www.bawaslu-dki.go.id.

Fenyapwain, M. M. (2013). Pengaruh iklan politik dalam pilkada Minahasa terhadap partisipasi pemilih pemula di Desa Tounelet Kecamatan Kakas. Jurnal Acta Diurna, 1(1), 1-16.

Gaffar, A. (1992). Pembangunan hukum dan demokrasi. Yogyakarta: UII Press.

Hadiz, V. R. (2004). Decentralization and democracy in Indonesia: a critique of neoinstitutionalist perspectives. Development and Change, 35(4), 697-718.

Hardiman, F. (1993). Menuju masyarakat komunikatif: ilmu, masyarakat, politik dan post-modernisme menurut Jurgen Habermas. Yogyakarta: Kanisius.

Hidayat, S. (2009). Pilkada, money politics, and the dangers of informal governance practices. In Deepening Democracy in Indonesia? Direct Elections for Local Leaders (pp.125-146). Singapore: Institute of Southeast Asian Studies.

Hill, H. (2012). Coruption and development: the Indonesian experience. In S. Khoman (Eds.), A Scholar for All: Essays in Honour of Medhi Krongkaew. Bangkok: Thammasat University Press.

Huntington, S. P. \& Joan M. N. (1977). No wasy choice: political participation an developing countries. Cambridge: Harvard University Press.

KPU. (2015). Keadilan dalam sengketa pilkada: menyongsong Pilkada serentak 2017. Jakarta: KPU RI.

Labolo, Muhadam. (2015). Dinamika politik dan pemerintahan lokal. Bogor: Ghalia Indonesia.

Laurian, L. (2004). Public participation in enveronmental decision making: finding from communities facing toxic waste cleanup. Journal of the American Planning Association, 70(1).

Lustrilanang, P. (2017). Kepemimpinan publik dalam penyelenggaraan Pilkada langsung: studi di DKI Jakarta (Dissertation, Universitas Brawijaya, 2017). Malang, Indonesia: FIA Universitas Brawijaya.

Mao, Zhenjun. (2010). Empirical analysis of rural citizen's politic participation in the underdeveloped regions of Chinese Eastern Provinces. Asian Social Science Review, 6(5), 160-174.

Mboi, A. B. (2009). Pilkada langsung: The first step on the long road to a dualistic provincial and district government. In M. Erb \& P Sulistiyanto (Eds.), Deepening Democracy in Indonesia? Direct Elections for Local Leaders. Singapore: Institute of Southeast Asian Studies.

Mikkelsen, B. (2011). Metode penelitian partisipatoris dan upaya pemberdayaan: panduan bagi pratisi lapangan. Jakarta: Yayasan Pustaka Obor Indonesia.

Mudjiyanto, B. (2012). Literasi internet dan partisipasi politik masyarakat pemilih dalam aktivitas pemanfaatan media baru: survey masyarakat pemilih pilkada kota Bengkulu. Jurnal Studi Komunikasi dan Media, 16(1), 1-16. Muhammad, F. (2015, December 14). DPD prihatin rendahnya partisipasi pemilih dalam pilkada serentak. Tribunnews.com. Retrieved from http://www.tribunnews. com/nasional/2015/12/14/dpd-ri-prihatinrendahnya-partisipasi-pemilih-dalampilkada-serentak. 
Muluk, M. R. Khaerul. (2009). Peta konsep desentralisasi dan pemerintahan daerah. Surabaya: ITS Press.

Nuryanti, S. (2015). Intervensi penyelenggaraan pemilukada: regulasi, sumberdaya dan eksekusi. Jurnal Ilmu Sosial dan Ilmu Politik, 19(2), 125-140.

Pratikno. (2009). Political parties in pilkada: some problem for democratic concolidation. In M. Erb \& P. Sulistiyanto (Eds.), Deepening Democracy in Indonesia? Direct Elections for Local Leaders. Singapore: Institute of Southeast Asian Studies.

Putnam, R. D., Leonardi, R., \& Nanetti, R. (1994). Making democracy work: civic traditions in modern Italy. Italy: Princeton University Press.

Rumesten, I. (2014). Korelasi perilaku korupsi kepala daerah dengan pilkada langsung. Jurnal Dinamika Hukum, 14(2), 189-367.

Rush, M., \& Phillip A. (2007). Pengantar sosiologi politik. Jakarta: Raja Grafindo Persada.

Sahdan, G., \& Muhtar, H. (2009). Evaluasi kritis penyelenggaraan pilkada di Indonesia. Yogyakarta: The Indonesian Power For Democracy (IPD).

Saifudin. (2009). Partisipasi publik dalam pembentukan peraturan perundang-undangan. Yogyakarta: FH UII Press.

Sari, I. P. (2016). Catatan hitam pemilihan Gubernur Sumatera Utara. Jurnal Transformative, 2(1), 86-102.

Sjahrir, B. S., Kis-Katos, R., \& Schulze, G. G. (2014). Administrative overspending in
Indonesian districs: the role of local politic. World Development, 59, 166-183.

Shehu, M., Dollani, P., \& Gjuta, D. (2013). Citizen participation and local good governance: case study - kukes region. Albanian Journal Agric, 12(4), 675-684.

Simamora, J. (2011). Eksistensi pemilukada dalam rangka mewujudkan pemerintahan daerah yang demokratis. Jurnal Mimbar Hukum, 23(1), 221-236.

Slamet, Y. (2001). Konsep-konsep dasar partisipasi sosial. Yogyakarta: Pusat Antaruniversitas Studi Sosial UGM.

Sundari, F.W. \& Ishak. (2017). Faktor penyebab rendahnya partisipasi pemilih dalam pemilihan bupati dan wakil bupati pelalawan di kecamatan Pangkalan Kerinci tahun 2015. Jurnal Jom Fisip, 4(1), 1-15.

Surbakti, Ramlan. (1992). Memahami ilmu politik. Jakarta: Granesia.

Suyatno. (2016). Pemilihan kepala daerah (Pilkada) dan tantangan demokrasi lokal di indonesia. Politik Indonesia: Indonesian Political Science Review, 1(2), 212-230.

Thananithichot, S. (2012). Political engagement and participation of thai citizen: the ruralurban disparaty. Journal of Contemporary Politics, 18(1), 87-108.

Tashandra, N. (2015, December 29). KPU: partisipasi pemilih pada pilkada serentak mencapai 70 persen. Kompas.com. Retrieved from https://nasional.kompas. com/read/2015/12/29/06461231/KPU. Partisipasi.Pemilih.pada.Pilkada.Serentak. Mencapai.70.Persen 